\title{
THE INTERNATIONAL POPULARISATION OF LESSON STUDY: EARLY STUDIES AND THEIR RELEVANCE IN LATER LITERATURE
}

\author{
LA INTERNACIONALIZACIÓN DEL \\ LESSON STUDY: PRIMEROS ESTUDIOS Y SU \\ RELEVANCIA EN LA LITERATURA POSTERIOR
}

doi: $10.21555 /$ rpp.v33i33.2397

Gabriel Hervas

Center for Research and Development of Higher Education, The University of Tokyo, Tokyo, Japan

gabriel@he.u-tokyo.ac.jp

https://orcid.org/0000-0002-0722-1063

Recibido: septiembre 22, 2021 - Aceptado: octubre 25, 2021

\begin{abstract}
Lesson study (LS) is a teachers' professional development practice with a Japanese origin that, at present, is practiced in more than 30 countries. Literature on LS acknowledges the works of Stigler and Hiebert and of Yoshida in 1999 as the origin of its internationalization. However, earlier studies described its practice and have mostly remained under the radar of LS previous research. This historical and documentary literature review sheds light on these previous studies describing LS, analyses their bibliometric relevance, and uncovers the first use of «lesson study» as the terminology adopted in the international literature. Results reveal eight studies clearly describing LS before 1999 and more oblique references in the 1980s. «Lesson study» appeared first in 1997, but we make the case for the previous use of other terminology. Findings also show that only those studies written by authors who later became key in the field of LS have received a high number of citations. These results bring attention to LS-related literature that has infrequently been cited, granting it recognition in the international history of LS, and expanding our current view in relation to its practice.
\end{abstract}

Keywords: Lesson Study, History of Education, Internationalization, Literature Review. 


\section{RESUMEN}

El lesson study (LS), frecuentemente traducido al español como «estudio de clases» o «estudio de lecciones», es una práctica de origen japonés relacionada con el desarrollo profesional del profesorado que, en la actualidad, es practicada en más de 30 países. La literatura sobre LS reconoce los trabajos de Stigler y Hiebert y de Yoshida (1999, ambos) como el origen de su internacionalización. Sin embargo, estudios previos describían su práctica y han permanecido mayoritariamente bajo el radar de la investigación sobre LS. Esta revisión histórica y documental de la literatura, arroja luz sobre estos estudios anteriores, describiendo el LS, analizando su relevancia bibliométrica, y descubriendo el primer uso de «lesson study», terminología adoptada en la literatura internacional.

Los resultados revelan -previamente a 1999- ocho estudios que describen el LS y más referencias indirectas ya en los años 80 . El concepto de «lesson study» apareció por primera vez en 1997, pero aquí se analiza en relación con el empleo anterior de esa terminología. Los resultados también muestran que únicamente aquellos estudios escritos por autores, que luego han sido clave en el campo del LS, han recibido un alto número de citas. Estos resultados llaman la atención sobre la literatura relacionada con el LS poco citada, otorgándole reconocimiento en la historia internacional de este término para expandir nuestra visión actual sobre su práctica.

Palabras clave: estudio de clases, estudio de lecciones, historia de la educación, internacionalización, «lesson study», revisión de literatura.

\section{INTRODUCTION}

Lesson study (LS) is a Japanese originating practice that is a central component of the professional development and in-service training (kounai kenshuu) of Japanese teachers (Fernandez \& Yoshida, 2004; Stigler \& Hiebert, 1999). LS consists of a process through which groups of teachers collaborate to plan and design a research lesson, teach, and observe its instruction, and discuss and reflect about it (Ermeling \& Ermeling, 2014; Hervas \& Medina, 2020; Stigler \& Hiebert, 1999; Takahashi \& McDougal, 2016); a cycle that, optionally (Fernandez \& Yoshida, 2004; Lewis, 2009), can continue with a new instruction of the revised lesson and the public report of the lesson and what has been learned through the process. Given this process, it is considered that LS supports teachers' learning (Bocala, 2015; Dudley, 2013; Perry \& Lewis, 2009) and efficacy (Chong \& Kong, 2012) and that it contributes to enhance teaching and instruction (Hiebert \& Stigler, 2017; Lewis et al., 2006) and to develop the pedagogical content knowledge (Coenders \& Verhoef, 2019). These positive outcomes have contributed to the international growth of LS since the end of the 1990s and to its transference to different educational levels and contexts, including higher education (Hervas, 2021).

\section{BACKGROUND}

In the English language, the history of LS in Japan has been addressed in different studies (Fernandez \& Yoshida, 2004; Ishii, 2016; Isoda, 2007; Makinae, 2019; Sarkar Arani et al., 2010; Shimizu \& Chino, 2015). Also, while not explicitly describing LS, Sato (1991, p. 6) wrote about its origin and linked it to the Herbartians' formal five steps. These studies generally set the emergence of LS-related practices in Japan at the end of the $19^{\text {th }}$ century or the very beginning of the $20^{\text {th }}$, within the Meiji era (1868-1912), although we find a work 
that, differently to others, briefly addresses this topic and points out a more contemporary origin for LS itself (Matoba, 2017).

Currently, we find LS in different international educational contexts, where there have been found misconceptions (Fujii, 2014) and variations (Norwich, 2018) in its practice; among these variations, learning study -an approach that was developed integrating design experiments with LS and incorporating elements from variation theory (Pang \& Marton, 2003; Marton \& Pang, 2006)- has been the most successful.

The popularisation of LS, as a significant process for teachers' induction and acculturation (Howe, 2006) occurred after a period of increasing interest in Japanese education during the 1980s and 1990s, in many cases focused on comparing it with US education. The list of English references from this period is long and, but the work by authors such as Beauchamp (1991), Cummings (1980), Horio (1988), Lewis (1995), Rohlen (1983), Rohlen and Björk (1998), Rohlen and LeTendre (1996), Shimahara and Sakai (1995), Stevenson (1991), and Stigler et al. (1987) deserves highlighting. Most of these texts address practices and activities that Japanese school and high-school teachers carried out, although they do not provide a clear description of LS. However, they are of interest in the context of this study because they had an impact on authors who later wrote about LS, or they were written (or contained texts written) by authors who are fundamental to understanding the expansion and our current comprehension of what LS is; that is the case of Hiebert, Fernandez, Lewis, Stigler, and Yoshida.

To this day, a vast number of studies, written also by Japanese authors, acknowledge Stigler and Hiebert (1999) and Yoshida (1999a) as key studies for the international popularisation of LS (e.g., Bjuland \& Mosvold, 2015; Fujii, 2014; Saito, 2012; Shimizu \& Chino, 2015; Takahashi \& McDougal, 2016). Stigler and Hiebert's is a book in which LS is defined as a useful approach for the improvement of teaching and in which its potential transfer to the US is discussed. In contrast, Yoshida's is an unpublished dissertation based on the author's ethnographic work in Japan. Fortunately, Yoshida gave visibility to his dissertation through a conference paper (Yoshida, 1999b) and, especially, through a book published years later with Fernandez (Fernandez \& Yoshida, 2004).

The relevance of Stigler and Yoshida as key authors for the internationalisation of LS is not coincidental; the authors knew each other and, especially between 1993 and 1996, collaborated on different papers with Fernandez (e.g., Stigler et al., 1996). However, the welldeserved acknowledgment of their 1999 work has sometimes come through statements that might have given the impression that they were the first to talk about LS to an international audience. Pang and Marton (2003, p. 175) claimed that Stigler and Hiebert were responsible for the introduction "to the West of the Japanese approach of "lesson study"», Doig and Groves (2011, p. 77) described Stigler and Hiebert's work as the means through which LS 'was released outside Japan', and Crockett (2002, p. 610) went even further and wrote that when she met Stigler, Hiebert and Yoshida in 1997 «there were virtually no English language materials available on Japanese professional development». These authors did not state that Stigler and Hiebert and Yoshida were the first to introduce and inform us about LS outside of Japan, but these types of assertions -common in LS-related literature-illustrate that it might have been not difficult for their readers to draw these conclusions.

This potential misconception is precisely what set this study in motion. Stigler and Hiebert (1999) wrote that «very little has been written about the process of «lesson study». An interest in knowing their sources and references, in exploring if we were missing previous studies informing us about LS, and in granting any earlier studies their place in the history of LS, all together, was transformed into the research questions that this study aims to answer. 


\section{METHODS}

\section{Focus of this Research}

The aim of this study is to answer the following questions:

a) Prior to Stigler and Hiebert and Yoshida, do we find studies clearly describing LS? If so, what are these studies?

b) Was the term «lesson study» used before 1999? If so, when was it used for the first time? Do we find alternatives in earlier literature?

c) If there are studies before 1999 describing LS, how many citations have they received and how much are they cited, if we compare them with Stigler and Hiebert, Yoshida, and other relevant studies published to date?

\section{Procedure, Data Collection and Analysis}

The methodological design of this study combined: a) search and review of the literature adjusting the PRISMA guidelines (Moher et al., 2009), as this research was more of a historical nature; b) systematic backward snowballing (Jalali \& Wohlin, 2012); and c) bibliometric search.

Google Scholar was used to conduct the literature search and obtain bibliometric information because recent scientometric studies have found that it is the most comprehensive academic search engine and bibliographic database (Gusenbauer, 2019) and that it offers significant additional coverage compared to World of Science and SCOPUS (Martín-Martín et al., 2018).

The procedure conducted was as follows:

a) Preliminary literature search to find any LS-related studies published before 1999 and to collect LS-related studies published during the first years of the international popularisation of LS (1999 to 2006). This was done to use their reference lists to go back in time for earlier publications by conducting a backward snowballing review of the literature, a powerful method to detect, precisely, less visible references (Greenhalgh \& Peacock, 2005).

For this preliminary search, «lesson study» as used as a key term and combined through Boolean operators (OR and AND) with terms such as «Japan», «education», «teacher», «training», «collaboration», «expansion», «origin», «history», «popularisation», «lesson design», «research lesson», etc. All types of documents (book chapters, journal and conference papers, theoretical studies, etc.) were collected for the later backward snowballing if they met two inclusion criteria: written in the English language and until 2006. The limit was 2006 because the first international conference of the World Association of Lesson Studies took place that year and it was when one of the most-cited LS-related texts (Lewis et al., 2006) was published. we took these facts as evidence that by 2006, LS was already an internationally recognised practice.

b) Removal of duplicates and screening of title and abstract to determine if the references found in the preliminary search were LS-related. 
c) Backward snowballing of the reference lists of the studies that passed the screening to find potential LS-related references from before 1999.

d) Removal of duplicates and screening to examine if the new references found and published before 1999 were LS-related.

e) New backward snowballing of the reference lists of the studies that passed the screening. This backward snowball search finished when no new LS-related references published before 1999 were found.

f) Full-text review and content analysis (Hsieh \& Shannon, 2005) of the all the selected LSrelated references published before 1999 to identify excerpts that were clearly describing LS and examine the terminology used.

In this research, a clear description of LS is defined as:

1. Not fragmented through many different paragraphs or pages.

2. Mentions design, teaching, observation, and discussion of a lesson conducted by Japanese teachers.

3. Indicates the collaborative nature of the process starting from the design of the lesson.

g) Bibliometric search in Google Scholar with two goals:

1. To find out the number of citations of the selected studies, their origin and year of publication.

2. To find out the most-cited LS-related reference published each year until 2019 (last year completed when this research has been conducted) and its numbers of citations.

\section{FINDINGS}

The previous analysis allowed us to answer the three research questions. Table 1 answers the first question by presenting the studies that clearly described the practice of LS before 1999.

\section{Studies Before 1999 Clearly Describing LS and Number of Citations}

\begin{tabular}{|l|l|c|}
\hline \multicolumn{1}{|c|}{ Reference } & \multicolumn{1}{c|}{ Excerpt that we can relate to LS } & $\begin{array}{c}\text { Number of } \\
\text { citations }\end{array}$ \\
\hline $\begin{array}{l}\text { Shimahara } \\
(1998, \text { p. } 456)\end{array}$ & $\begin{array}{l}\text { «Preparation for each demonstration class involves } \\
\text { extensive peer participation lasting two to three months. } \\
\text { At each grade level teachers are chosen to be observed } \\
\text { on a rotational basis, and faculty of each grade group } \\
\text { collaborate in helping those chosen teachers to prepare } \\
\text { their lessons. After a demonstration, staff members meet } \\
\text { to review their observations and critique the class». }\end{array}$ & \\
\hline
\end{tabular}




\begin{tabular}{|c|c|c|}
\hline $\begin{array}{l}\text { Lewis and } \\
\text { Tsuchida } \\
(1998, \mathrm{pp} \text {. } \\
\text { 48-49) }\end{array}$ & $\begin{array}{l}\text { «Research lessons are actual classroom lessons, taught } \\
\text { to one's own students, but they embody a number of } \\
\text { special features that set them apart from an everyday } \\
\text { class: They are observed by other teachers, [...], they are } \\
\text { carefully planned, usually in collaboration }[\ldots] \text {, they are } \\
\text { recorded [...], they are discussed [...]». }\end{array}$ & $\begin{array}{l}690 \text { (includes } \\
\text { citations from } \\
\text { the same paper } \\
\text { published in a } \\
\text { different journal } \\
\text { during 1999) }\end{array}$ \\
\hline $\begin{array}{l}\text { Lewis and } \\
\text { Tsuchida } \\
\text { (1997, pp. } \\
\text { 320-321) }\end{array}$ & $\begin{array}{l}\text { «[...] research lessons are designed to show how an } \\
\text { abstract goal can be fostered in the classroom, or to } \\
\text { demonstrate innovations in curriculum materials [...] is } \\
\text { ultimately taught by one teacher - with many colleagues } \\
\text { crowded into the sides of the classroom to observe and } \\
\text { record - it is often planned and tested by a group of } \\
\text { teachers working collaboratively for many months». }\end{array}$ & 159 \\
\hline $\begin{array}{l}\text { Stigler and } \\
\text { Hiebert } \\
(1997, \text { p. 62) }\end{array}$ & $\begin{array}{l}\text { "A key part of this process is their participation in "lesson } \\
\text { study groups". Small groups of teachers meet regularly, } \\
\text { once a week for about an hour, to plan, implement, } \\
\text { evaluate, and revise lessons collaboratively». }\end{array}$ & $\begin{array}{l}603 \text { (includes } \\
\text { citations from } \\
\text { the same text } \\
\text { published both as } \\
\text { a conference and } \\
\text { a journal paper) }\end{array}$ \\
\hline $\begin{array}{l}\text { Ichimura, } \\
1993(1993, \\
\text { pp. 8-9) }\end{array}$ & $\begin{array}{l}\text { «[...] material used in the classroom study is [...]. The } \\
\text { aim of this class, which teachers had earlier agreed on } \\
{[\ldots] . \text { The classroom observation report involving the }} \\
\text { teaching }[\ldots] \text { was presented by three teachers and it was } \\
\text { followed by comments from participants and advisers». }\end{array}$ & 9 \\
\hline $\begin{array}{l}\text { Nagasaki } \\
\text { and Becker } \\
(1993, \text { p. } 8)\end{array}$ & $\begin{array}{l}\text { «...] any such experiences are classroom and } \\
\text { research-based in that teachers develop a lesson plan } \\
\text { cooperatively, then one teacher (a representative of } \\
\text { the group) teaches the lesson while the other teachers } \\
\text { observe the lesson in progress, and afterward a record } \\
\text { of the lesson is written and the teachers discuss it». }\end{array}$ & 29 \\
\hline $\begin{array}{l}\text { Takemura } \\
\text { and Shimizu } \\
\text { (1993, pp. } \\
\text { 31-32) }\end{array}$ & $\begin{array}{l}\text { «[...] newly recruited teachers would be given the } \\
\text { chance to demonstrate lessons for experienced teachers } \\
{[\ldots] \text {. During the demonstration, the experienced }} \\
\text { teachers would observe the class of the newly recruited } \\
\text { teacher }[\ldots] \text {. The meeting for evaluating and improving } \\
\text { the lesson of the newly recruited teacher's lessons, is } \\
\text { determined during this gathering. After the teacher's } \\
\text { demonstration, each group of teachers presents the } \\
\text { newly revised lesson plan [...]. Each group of teachers } \\
\text { can present a new lesson plan to the workshop } \\
\text { participants». }\end{array}$ & 19 \\
\hline $\begin{array}{l}\text { Stevenson } \\
\text { and Stigler } \\
(1992, \text { p. } 160)\end{array}$ & $\begin{array}{l}\text { «She and her colleagues spend a good deal of their } \\
\text { time together working on lesson plans. After they } \\
\text { finish a plan, one teacher from the group teaches the } \\
\text { lesson to her students while the other teachers look } \\
\text { on. Afterward, the group meets again to evaluate the } \\
\text { teacher's performance and to make suggestions for } \\
\text { improvement». }\end{array}$ & 2830 \\
\hline
\end{tabular}


The analysis of studies in Table 1 allows to respond the second research question and reveals that the first explicit use of the terms «lesson study» appeared in Stigler and Hiebert (1997, p. 62) when they wrote: «A key part of this process is their participation in "lesson study groups"». However, the analysis also shows that we find a potential earlier translation in Ichimura (1993, p. 8) as «classroom study».

Beyond these eight studies, there are others -Becker (1989), Cummings (1980), Hawley and Hawley (1997), Hayakawa (1986), Inagaki (1993), King and Mizoue (1993), Obara et al. (1993), Leestma et al. (1987), Sato (1991), Sato et al. (1993), Sato and McLaughlin (1992), Shimahara (1979; 1991), Stigler et al. (1996)- in which we find excerpts that, less clearly, we can relate to LS. We even find one study (Nagasaki \& Hashimoto, 1984, p. 180) describing the same steps of LS, although in this case they appear as strategies that the participants (teachers) carried out for research purposes, and not as tasks that they performed as part of their job routines.

However, these studies (except for the last one) only display fragmentary or partial depictions of LS and of some of its features, or refer to LS-related practices (e.g., demonstration classes) and, for this reason, they do not offer a clear description of LS as defined in this study. To illustrate these cases not included in Table 1, here follows an excerpt from Sato (1993, p. 133) that offers one of the clearest descriptions of an LS-related practice, only failing to refer to lesson design and its collaborative nature (actually, it seems that the observed teacher designed the activity/lesson alone, as he/she distributed its explanation later, when the group met to reflect on it):

[...] inservice training consists of teachers observing another teacher for one class period [...]. Then, in a teachers' meeting after school, the observed teacher distributes an explanation of the activity and reflects upon the lesson, including self-evaluation. Following the reflective activity, others contribute comments and questions [...].

Regarding the third research question, Table 1 displays the number of citations received by the studies found before 1999 and reveals that there are three studies from 1993 with clearly a lower number of citations. The origin of their citations was revised and is shown in Table 2.

Origin of the Citations of the Three Less Cited Studies

Published Before 1999

\begin{tabular}{|l|l|l|l|}
\hline & $\begin{array}{l}\text { Ichimura } \\
(1993)\end{array}$ & $\begin{array}{l}\text { Nagasaki and } \\
\text { Becker (1993) }\end{array}$ & $\begin{array}{l}\text { Takemura and } \\
\text { Shimizu (1993) }\end{array}$ \\
\hline Number of citations & 9 & 29 & 19 \\
\hline English language citations & $9 / 9$ & $22 / 29$ & $18 / 19$ \\
\hline Document citing found & $9 / 9$ & $20 / 22$ & $17 / 18$ \\
\hline $\begin{array}{l}\text { Real number of citations once } \\
\text { revised }\end{array}$ & $9 / 9$ & $18 / 20$ & $15 / 17$ \\
\hline LS-related citations & $0 / 9$ & $6 / 18$ & $11 / 15$ \\
\hline LS-related citations last 10 years & 0 & 2 & 3 \\
\hline Observations & - & $\begin{array}{l}2 / 6 \text { studies } \\
\text { by Yoshinori } \\
\text { Shimizu }\end{array}$ & $\begin{array}{l}4 / 11 \text { studies by } \\
\text { Stigler and } / \text { or } \\
\text { Hiebert }\end{array}$ \\
\hline
\end{tabular}


Also, as Figure 1 demonstrates, the studies of Nagasaki and Becker and Takemura and Shimizu were mainly cited in LS-related studies between 1999 and 2003, with only five citations in the last 10 years; on a different hand, none of Ichimura's citations are LS-related.

Year and number of LS-related studies citing Takemura and Shimizu and Nagasaki and Becker

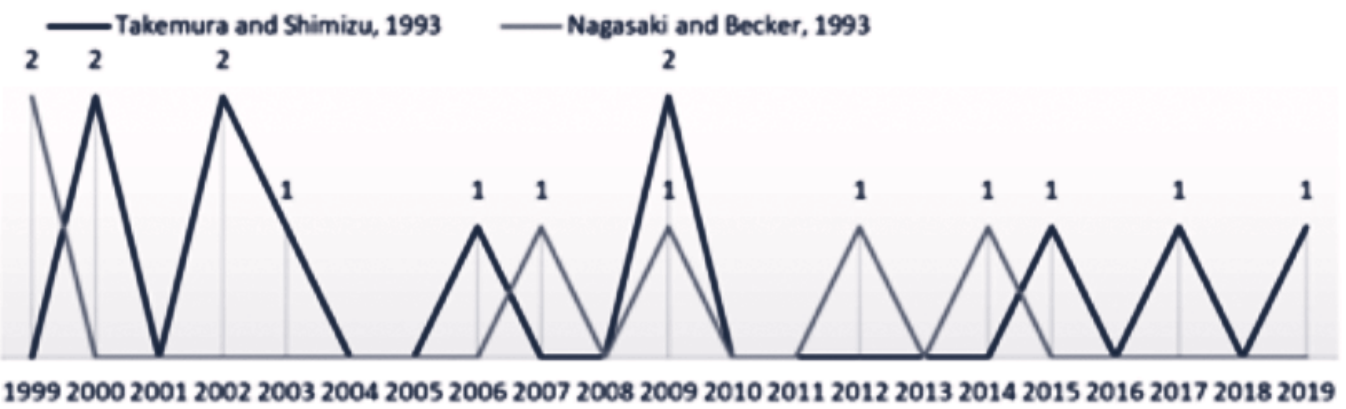

Finally, in comparison with Table 1, Table 3 shows the number of citations for Stigler and Hiebert (1999) and Yoshida's dissertation-related publications, as well as for the most-cited LS-related references published annually from 1999 to 2018.

Citations of studies published between 1999-2018

\begin{tabular}{|l|l|l|}
$\begin{array}{c}\text { Year of } \\
\text { publication }\end{array}$ & \multicolumn{1}{c|}{ Reference } & \multicolumn{1}{c|}{ Number of citations } \\
\hline 1999 & Stigler and Hiebert (1999) & 5848 \\
\hline 1999 & Yoshida (1999a) & 226 \\
\hline 1999 & Yoshida (1999b) & 117 \\
\hline 2000 & Lewis (2000) & 385 \\
\hline 2001 & Fernandez et al. (2001) & 51 \\
\hline 2002 & Lewis (2002) & 1123 \\
\hline 2003 & Fernandez et al. (2003) & 491 \\
\hline 2004 & Fernandez and Yoshida (2004) & $\begin{array}{l}870 \quad \text { (Includes e-book version } \\
\text { published in 2012) }\end{array}$ \\
\hline 2005 & Rock and Wilson (2005) & 236 \\
\hline 2006 & Lewis et al. (2006) & 920 \\
\hline 2007 & Isoda et al. (2007) & $\begin{array}{l}239 \text { (combining English and } \\
\text { Spanish version of the book) }\end{array}$ \\
\hline & & \\
\hline & & \\
\hline & &
\end{tabular}




\begin{tabular}{|l|l|l|}
\hline 2008 & Lee (2008) & 128 \\
\hline 2009 & Lewis et al. (2009) & 404 \\
\hline 2010 & Ono and Ferreira (2010) & 267 \\
\hline 2011 & Murata (2011) & 227 \\
\hline 2012 & Chong and Kong (2012) & 164 \\
\hline 2013 & Dudley (2013) & 183 \\
\hline 2014 & Dudley (2014) & $\begin{array}{l}134 \text { (includes an earlier edition of } \\
\text { the handbook in 2011) }\end{array}$ \\
\hline 2015 & Bjuland and Mosvold (2015) & 66 \\
\hline 2016 & Takahashi and McDougal (2016) & 110 \\
\hline 2017 & Lewis and Perry (2017) & 46 \\
\hline 2018 & Coenders and Verhoef (2019) & 23 (paper published on-line in \\
\hline & & $2018)$ \\
\hline
\end{tabular}

\section{DISCUSSION}

Results show that, before the studies commonly acknowledged as the origin of the internationalisation of LS, there were others in English describing LS with different levels of clarity. Starting at least from Stevenson and Stigler (1992), we find a clear description, but we must wait until Stigler and Hiebert (1997) to find the term «lesson study».

Stigler wrote for the foreword of Fernandez and Yoshida (2004) that Yoshida was the person who first introduced LS to him; however, we do not have information regarding who decided on an English translation -actually, Stigler and Hiebert (1997) did not make any reference to this or to Yoshida in their paper-and, in consequence, we cannot substantiate Panićs (2014, p. 84) claim that "the term "lesson study" was coined in 1999 by Makoto Yoshida in his doctoral dissertation». It is also noticeable that, although «lesson study» appears in 1997, the two LS-related references published one year later (Lewis \& Tsuchida, 1998; Shimahara, 1998) did not use this terminology. We lack information regarding when, during 1998, Shimahara (1998) was published; the author did not cite the work of Stigler and Hiebert and he used an alternative terminology: «study classes». In contrast, Lewis and Tsuchida (1998) cited the work of Stigler and Hiebert (1997), but they did not use their terminology and only referred to research lessons (interestingly enough, instead of research lesson, Fernandez and Yoshida [2004] preferred to talk about study lessons. See Horio [1988, pp. 250-251] for an interesting political and educational debate about the translation of kenkyuu as research or study). In any case, early in January 1999, we already find a text (Shimizu ,1999, p. 112) that uses this terminology and explicitly talks about «lesson study meetings». Notably, this study does not cite Stigler and Hiebert (1997) and was based on an earlier version presented at a conference in 1996 (document not available for reading). If that version from 1996 were also to include the terms «lesson study», it should receive credit for being the first published document using the terminology we use today to translate jugyou kenkyuu.

In relation to the terminology used, besides Shimahara's (1998, p. 456) translation as «study classes», results show that Ichimura (1993, p. 8) might have offered an alternative 
nomenclature before 1997: "classroom study» (see Table 1). It is unclear if the author is referring to the practice of analysing classrooms/lessons, but we should consider different arguments that, even if they are not definitive, make a case for an earlier and different LS translation:

a) In Ichimura (1993) we find a description that we can relate to LS.

b) In it, we find cited Manabu Sato, a Japanese professor famous for his work in relation to LS and who had earlier talked about «case study workshops» to refer to an LS-related process (Sato, 1991, p4).

c) Even if jugyou can be translated as lesson or instruction, it can also be translated as class (as in «history class»). Shimahara (1998) used that alternative translation in his «study classes» terminology and Shimizu and Chino (2015) also wrote that jugyou can be translated as classroom lessons.

Regarding the studies published before 1999 clearly describing LS, as seen in Table 1, Stigler authors two of the eight studies. These two studies have received a significant number of citations, although far fewer than Stigler and Hiebert (1999) (see tables 1 and 3). In Stevenson and Stigler (1992) the description of LS only appears as an explanation of what teachers in a school did, without further details about it or any indication of whether it was a common practice across Japan. In contrast, in Stigler and Hiebert (1997), LS is central to the article's purpose and, therefore we can conclude that its high number of citations might be related to a growing interest in LS.

Table 1 also shows two other studies written by the same authors: Lewis and Tsuchida (1997; 1998). In both articles, research lessons are a central topic, and therefore we can conclude that their high number of citations reflects an interest in LS among citing authors. Also, in the case of the 1998 study, its re-publishing in a different journal the following year might have helped to increase its visibility. However, more than anything, the high number of citations of these studies can find an explanation in the relevance that Lewis has in the field of LS. As Table 3 evinces, her studies appear among the most cited in different years and she receives recognition as key for our understanding of LS and also for its popularisation (Takahashi \& McDougal, 2016); an acknowledgment we find even before 1999, when Stigler and Hiebert (1997) invited anyone interested in learning more about LS to read Lewis and Tsuchida (1997), a study still in press at the time.

So far, we have discussed two group of studies before 1999 that clearly described LS. As their number of citations show, these studies are known by other scholars, and they should also receive credit for the international introduction and emergence of LS. However, Table 1 shows four other studies clearly describing LS before that date, but with fewer citations, especially those from 1993. One of them is Shimahara (1998), an article cited in Stigler and Hiebert (1999) and written by a well-known author among those interested in Japanese education. The other three are articles from 1993 that, as their number of citations reveals (see Table 1), have remained clearly underrepresented in later literature. Even more, as Table 2 and Figure 1 demonstrate, a possible explanation for their low number of citations is bibliographic, as they were mainly cited between 1999 and 2003 and many of their citations came from the same authors (especially, Yoshinori Shimizu and Stigler and Hiebert). In consequence, the chances of knowing these three articles are slim if not reading Shimizu, Stigler and Hiebert or if reading LS-related literature after 2003.

Figure 1 also shows that none of these studies from 1993 were cited in relation to LS before 1999, which also means that none of the other studies in Table 1 cited them. On the one hand, Lewis and Tsuchida $(1997 ; 1998)$ and Shimahara $(1998)$ do not mention them, 
although Shimahara refers to other studies from the special issues of the Peabody Journal of Education in which Takemura and Shimizu (1993) and Ichimura (1993) were published. On the other hand, Stigler and Hiebert $(1997 ; 1999)$ acknowledge the special issues of the Peabody Journal of Education as one of their bases for writing about the Japanese process of teaching improvement. However, while they specifically mention the influence of other authors (Lewis, Tsuchida, Shimahara, Sakai and Yoshida), they do not specify which studies from these issues were used to write their descriptions (Stigler \& Hiebert, 1997 p. 21): «[...] a number of written sources, including [...] and two special issues of the Peabody Journal of Education devoted to Japanese teacher education (Spring and Summer 1993)». Later in 1999 (p. 191), they specify the volume and number of the special issue, but the authors remain absent. Despite this, we can assume that Stigler and Hiebert (1999) were basically referring to Takemura and Shimizu (1993), because they cite this study in a different passage and because, as seen in Table 2, in later texts (e.g., Hiebert \& Stigler, 2000; Hiebert et al., 2002) they finally mention it as one of their sources for talking about LS.

Although it should not be considered the only criteria, the number of citations of a study speaks, more than about its quality, about its relevance in the literature. As seen for the studies from 1993, even if the information offered by Stigler and Hiebert could have led later researchers to find some of them, their number of citations shows that they have remained in the shadows. The case of Yoshida's dissertation (1999a) also stands out because, despite being recognised as key for the internationalisation of LS, most studies published immediately before or after it (see Table 3) are more cited. This is likely because the dissertation was unpublished, and it brings attention to what makes studies in Table 3 the most cited (scientific quality, authors' relevance, accessibility of the publication, re-publishing in different formats -journal paper, conference paper, book chapter...- self-citations, etc.), a topic that deserves further exploration in future studies.

\section{CONCLUSION, LIMITATIONS, AND VALUE OF THIS RESEARCH}

Stigler and Hiebert (1999) and Yoshida (1999a) have been acknowledged as key for the international popularisation of LS, and their impact in later research has been shown in this study, especially in the case of Stigler and Hiebert's work. However, this research shows that, prior to these, earlier studies offered a clear description of LS beginning in 1992 (and hazier descriptions even earlier), and that the term «lesson study» was first used in 1997, although alternative translation might have appeared before. Some of these studies published before 1999 -written by authors who later became influential in the field of LS-are recognised in the literature, as their number of citations suggests. On the other hand, another group of studies, especially three from 1993, have remained underrepresented in later literature and unknown to most researchers.

Despite these findings, some limitations of this research deserve to be mentioned. First, criteria set regarding what counts as clear description of LS might not be shared by others. Also, further research should approach citations in LS in a more precise manner to uncover the bibliographic relevance across time of different studies. Finally, in spite of conducing this research in Japan, it was not possible to access the conference presentation by Shimizu in 1996 or the dissertations of Sato and Tsuchida, from 1991 and 1993 respectively. Regardless of its limitations, this study reveals and grants recognition to studies that deserve a spot in the international history of LS -and, in consequence, of learning study- and that have been overlooked in later literature. 


\section{REFERENCES}

Beauchamp, E. R. (Ed.) (1991). Windows on Japanese education. Greenwood Press.

Becker, J. P. (Ed.) (1989). Mathematics Teaching in Japanese Elementary and Secondary Schools Report of the ICTM Japan Mathematics Delegation. https:/ / files.eric.ed.gov/fulltext/ ED308070.pdf

Bjuland, R. \& Mosvold, R. (2015). Lesson study in teacher education: Learning from a challenging case. Teaching and teacher education, 52, 83-90. https://doi.org/10.1016/j. tate.2015.09.005

Chong, W. H. \& Kong, C. A. (2012). Teacher Collaborative Learning and Teacher Self-Efficacy: The Case of Lesson Study. The Journal of Experimental Education, 80(3), 263-283. https://doi.org/10.1080/00220973.2011.596854

Coenders, F. \& Verhoef, N. (2019). Lesson Study: professional development (PD) for beginning and experienced teachers. Professional Development in Education, 45(2), 217230. https:// doi.org/10.1080/19415257.2018.1430050

Crockett, M. D. (2002). Inquiry as professional development: creating dilemmas through teachers' work. Teaching and teacher education, 18. 609-624. https:/ / doi.org/10.1016/ $\underline{\text { S0742-051X(02)00019-7 }}$

Cummings, W. (1980). Education and Equality in Japan. Princeton University Press.

Doig, B. \& Groves, S. (2011). Japanese lesson study: Teacher professional development through communities of inquiry. Mathematics teacher education and development, 13(1), 77-93. http://hdl.handle.net/10536/DRO/DU:30043312

Dudley, P. (2013). Teacher learning in lesson study: What interaction-level discourse analysis revealed about how teachers utilised imagination, tacit knowledge of teaching, and fresh evidence of pupils' learning, to develop practice knowledge and so enhance their pupils' learning. Teaching and Teacher Education, 34, 107-121. https:/ / doi. org/10.1016/j.tate.2013.04.006

Dudley, P. (2014). Lesson Study: a handbook. http:/ / disde.minedu.gob.pe/bitstream/handle $/ 123456789 / 5017 /$ Lesson $\% 20$ Study $\% 20 a \% 20$ Handbook.pdf?sequence=1\&isAllowed $=\mathrm{y}$

Ermeling, B. A. \& Graff-Ermeling, G. (2014). Learning to learn from teaching: a first-hand account of lesson study in Japan. International Journal for Lesson and Learning Studies, 3(2), 170-191. https: / / doi.org/10.1108/IJLLS-07-2013-0041

Fernandez, C., \& Yoshida, M. (2004). Lesson study: A Japanese approach to improving mathematics teaching and learning. Lawrence Erlbaum Associates.

Fernandez, C., Cannon, J. \& Chokshi, S. (2003). A US-Japan lesson study collaboration reveals critical lenses for examining practice. Teaching and teacher education, 19(2), 171-185. https:/ / doi.org/10.1016/S0742-051X(02)00102-6

Fernandez, C., Chokshi, S., Cannon, J. \&Yoshida (2001). Learning about lesson study in the United States. In E. Beauchamp (Ed.), New and old voices on Japanese education (pp. 56-72). Sharke. 
Fujii, T. (2014). Implementing Japanese Lesson Study in Foreign Countries: Misconceptions Revealed. Mathematics Teacher Education and Development, 16(1), 65-83. https:// eric.ed.gov / ?id=EJ1046666

Greenhalgh, T. \& Peacock, R. (2005). Effectiveness and efficiency of search methods in systematic reviews of complex evidence: audit of primary sources. BMJ, 331(7524), 1064-1065. https:// doi.org/10.1136/bmj.38636.593461.68

Gusenbauer, M. (2019). Google Scholar to overshadow them all? Comparing the sizes of 12 academic search engines and bibliographic databases. Scientometrics, 118(1), 177214. https:// doi.org/10.1007/s11192-018-2958-5

Hawley, C. A. \& Hawley, W. D. (1997). The role of universities in the education of the Japanese teachers: A distant perspective. Peabody Journal of Education, 71(1), 233-244. https://doi.org/10.1207/s15327930pje7201 13

Hayakawa, M. (1986). The quality and socioeconomic status of teachers in Japan. Final report. Washington, DC.

Hervas, G. (2021). Lesson study as a faculty development initiative in higher education: A systematic review. AERA Open, 7(1), 1-19. https://doi. org $/ 10.1177 \% 2 \mathrm{~F} 2332858420982564$

Hervas, G. \& Medina, J. L. (2020). Key components of lesson study from the perspective of complexity: A theoretical analysis. Teachers and Teaching: Theory and Practice, 26(1), 118-128. https:// doi.org/10.1080/13540602.2020.1745174

Hiebert, J. \& Stigler, J. W. (2017). A Proposal for Improving Classroom Teaching: Lessons from the TIMSS Video Study. The Elementary School Journal, 101(1), 3-20. https:// doi.org/10.1086/499656

Hiebert, J. \& Stigler, J. W. (2017). Teaching Versus Teachers as a Lever for Change: Comparing a Japanese and a U.S. Perspective on Improving Instruction. Educational Researcher, 46(4), 169-176. https:/ / doi.org/10.3102\%2F0013189X17711899

Hiebert, J. Gallimore, R. \& Stigler, J. W. (2002). A knowledge base for the teaching profession: What would it look like and how can we get one? Educational Researcher, 46(4), 169-176. https: / / doi.org/10.3102\%2F0013189X031005003

Horio, T. (1988). Educational thought and ideology in modern Japan: state authority and intellectual freedom (S. Platzer, Ed. and Trans.). Tokyo University Press.

Howe, E. R. (2006). Exemplary Teacher Induction: An international review. Educational Philosophy and Theory, 38(3), 287-297. https:// doi.org/10.1111/j.1469-5812.2006.00195.x

Hsieh, H. F. \& Shannon, S. E. (2005). Three Approaches to Qualitative Content Analysis. Qualitative Health Research, 15(9), 1277-1288. https://doi. org $/ 10.1177 \%$ 2F1049732305276687

Ichimura, T. (1993). A philosophical approach to the «knowledge base» in teacher education: Recognizing the element of uncertainty in teaching. Peabody Journal of Education, 68(4), 3-15. https:// doi.org/10.1080/01619569309538737

Inagaki, T. (1993). The contemporary status of the teaching profession in Japan: Its roles, responsibilities, and autonomy. Peabody Journal of Education, 68(4), 88-99. https:// doi.org/10.1080/01619569309538744 
Ishii, T. (2016). Historical overview of lesson study. In K. Tanaka, K. Nishioka, \& T. Ishii (Eds.), Curriculum, instruction and assessment in Japan (pp. 57-72). Routledge.

Isoda, M. (2007). Where did lesson study begin, and how far has it come. In M. Isoda et al. (Eds.), Japanese lesson study in mathematics: It's impact, diversity and potential for educational improvement (pp. 8-15). World Scientific.

Jalali, S. \& Wohlin, C. (2012). Systematic Literature Studies: Database Searches vs. Backward Snowballing. Paper presented at the ESEM, Lund, Sweden.

King, A. \& Mizoue, Y. (1993). A case for university-based professional development and experimental schools: Japanese and American perspectives. Peabody Journal of Education, 68(3), 67-79. https:// www.jstor.org/stable/1492914

Lee, J. F. K. (2008). A Hong Kong case of lesson study-Benefits and concerns. Teaching and Teacher Education, 24(5), 1115-1124. https:// doi.org/10.1016/j.tate.2007.10.007

Leestma, R., August, R. L., George, B. \& Peak, L. (1987). Japanese education today. US Department of Education.

Lewis, C. C. (1995). Educating hearts and minds: Reflections on Japanese preschool and elementary education. Cambridge University Press.

Lewis, C. C. (2000). Lesson Study: The Core of Japanese Professional Development. Paper presented at the American Educational Research Association, New Orleans, LA.

Lewis, C. C. (2002). Lesson Study: A handbook of a teacher-led instructional change. Research for better schools.

Lewis, C. C. (2009). What is the Nature of Knowledge Development in Lesson Study? Educational Action Research, 17 (1), 95-110. https:// doi.org/10.1080/09650790802667477

Lewis, C. C. \& Perry, R. (2017). Lesson study to scale up research-based knowledge: A randomized, controlled trial of fractions learning. Journal for research in mathematics education, 48(3), 261-299. https: / / doi.org/10.5951/jresematheduc.48.3.0261

Lewis, C. C. \& Tsuchida, I. (1997). Planned educational change in Japan: the case of elementary science instruction. Journal of Education Policy, 12(5), 313-331. https:/ / doi. org $/ 10.1080 / 0268093970120502$

Lewis, C. C. \& Tsuchida, I. (1998). A lesson is like a swiftly flowing river: Research lessons and the improvement of Japanese education. American Educator, 22(4), 12-17 \& 50-52.

Lewis, C. C. Perry, R. \& Hurd, J. (2009). Improving mathematics instruction through lesson study: A theoretical model and North American case. Journal of mathematics teacher education, 12, 285-304. https:// doi.org/10.1007/s10857-009-9102-7

Lewis, C. Perry, R. \& Murata, A. (2006). How Should Research Contribute to Instructional Improvement? The case of lesson study. Educational Researcher, 35(3), 3-14. https:// doi.org/10.3102\%2F0013189X035003003

Makinae, N. (2019). The Origin and Development of Lesson Study in Japan. In R. Huang, A. Takahashi, \& J. Ponte (Eds.), Theory and Practice of Lesson Study in Mathematics. Advances in Mathematics Education (pp. 169-181). Springer. 
Martín-Martín, A., Orduna-Malea, E., Thelwall, M. \& López-Cózar, E. D. (2018). Google Scholar, Web of Science, and Scopus: a systematic comparison of citations in 252 subject categories. Journal of Informetrics, 12(4), 1160-1177. https://doi.org/10.1016/j. joi.2018.09.002

Marton, F. \& Pang, M. F. (2006). On some necessary conditions of learning. The Journal of the Learning sciences, 15(2), 193-220. https:/ / doi.org/10.1207/s15327809jls1502 2

Matoba, M. (2017). Building Academic-Oriented Lesson Study. Education and Research Bulletin of Tokai Gakuen University, 3, 120-134. http:/ / repository.tokaigakuen-u.ac.jp/ dspace/bitstream/11334/1492/1/spkiyo 003 12.pdf

Moher, D., Liberati, A., Tetzlaff, J. \& Altman, D. G. (2009). Preferred reporting items for systematic reviews and meta-analyses: the PRISMA statement. Annals of internal medicine, 151(4), 264-269. https:// doi.org/10.1136/bmj.b2535

Murata, A. (2011). Introduction: Conceptual Overview of Lesson Study. In L. C. Hart, A. Alston \& A. Murata (Eds.), Lesson Study Research and Practice in Mathematics Education (pp. 1-12). Springer.

Nagasaki, E. \& Becker, J. P. (1993). Classroom Assessment in Japanese Mathematics Education. US Department of Education.

Nagasaki, E. \& Hashimoto, Y. (1984). Various problems about research on teaching of developmental treatment of mathematical problems in grades 1-12. Paper presented at the International congress on mathematical education, Adelaide, Australia.

Norwich, B. (2018). Making sense of international variations in lesson study and lesson study-like practices. International Journal for Lesson and Learning Studies, 7(3), 201216. https: / / doi.org/10.1108/IJLLS-02-2018-0007

Obara, Y. Takahashi, Y. \& Nakazawa, K. (1993). How Japanese student teachers view practice teaching: An analysis of critical incidents summaries. Peabody Journal of Education, 68(4), 34-46. https: / / doi.org/10.1080/01619569309538740

Ono, Y. \& Ferreira, J. (2010). A case study of continuing teacher professional development through lesson study in South Africa. South African Journal of Education, 30(1), 59-74. https:// doi.org/10.15700/saje.v30n1a320

Pang, M. I. \& Marton, F. (2003). Beyond 'lesson study': Comparing two ways of facilitating the grasp of some economic concepts. Instructional Science, 31, 175-194. https:// doi.org/10.1023/A:1023280619632

Perry, R. R. \& Lewis, C. C. (2009). What is successful adaptation of lesson study in the US? Journal of Educational Change, 10(4), 365-391. https://doi.org/10.1007/s10833-0089069-7

Pjanić, K. (2014). The origins and products of Japanese lesson study. Inovacije u nastavi-časopis za savremenu nastavu, 27(3), 83-93. https://scindeks-clanci.ceon.rs/ data/pdf/0352-2334/2014/0352-23341403083P.pdf

Rock, T. C. \& Wilson, C. (2005). Improving teaching through lesson study. Teacher Education Quarterly, 32(1), 77-92. https:/ / files.eric.ed.gov/fulltext/EJ795305.pdf 
Rohlen, T. P. (1983). Japan's high school. University of California Press.

Rohlen, T. P. \& Björk, C. (Eds.) (1998). Education and Training in Japan. Vol. 1-3. Routledge

Rohlen, T.P. \& LeTendre, G. (Eds.) (1996). Teaching and learning in Japan. Cambridge University Press.

Saito, E. (2012). Key issues of lesson study in Japan and the United States: a literature review. Professional Development in Education, 38(5), 777-789. https: / / doi.org/10.1080 $\not 19415257.2012 .668857$

Sarkar Arani, M. R., Fukaya, K. \& Lassegard, J. P. (2010). «Lesson Study2 as Professional Culture in Japanese Schools: An Historical Perspective on Elementary Classroom Practices. Japan Review, 22, 171-200. https:/ / www.jstor.org/stable/25791346

Sato, M, (1991). Case method in Japanese teacher education: Traditions and our experiments. Paper presented at the 4th Annual Meeting of the Japan-United States Teacher Education Consortium, Stanford, CA.

Sato, M., Akita, K. \& Iwakawa, N. (1993). Practical thinking styles of teachers: A comparative study of expert and novice thought processes and its implications for rethinking teacher education in Japan. Peabody Journal of Education, 68(4), 100-110. https:// doi.org/10.1080/01619569309538745

Sato, N. (1993). Teaching and learning in Japanese elementary schools: A context for understanding. Peabody Journal of Education, 68(4), 111-153. https://doi. org/10.1080/01619569309538746

Sato, N., \& McLaughlin, M. W. (1992). Context matters: Teaching in Japan and in the United States. Phi Delta Kappan, 73(5), 359-366.

Shimahara, N. (1979). Adaptation and education in Japan. Greenwood Press.

Shimahara, N. (1991). Teacher education in Japan. In E. R. Beauchamp (Ed.), Windows on Japanese education (pp. 259-280). Greenwood Press.

Shimahara, N. K. (1998). The Japanese model of professional development. Teaching and Teacher Education, 14(5), 451-462. https: / doi.org/10.1016/S0742-051X(97)00055-3

Shimahara, N. \& Sakai, (1995). Learning to teach in two cultures: Japan and the United Stated. Garland.

Shimizu, S. \& Chino, K. (2015). History of lesson study to develop good practices in Japan. In M. Inprasitha, et al., (Eds.), Lesson study: Challenges in mathematics education (pp. 123-140). World Scientific.

Shimizu, Y. (1999). Aspects of mathematics teacher education in Japan: Focusing on teachers' roles. Journal of Mathematics Teacher Education, 2(1), 107-116. https:/ / doi. org/10.1023/A:1009960710624

Stevenson, H. W. (1991). Japanese Elementary School Education. The Elementary School Journal, 92(1), 109-120. https:// doi.org/10.1086/461682 
Stevenson, H. W. \& Stigler, J. W. (1992). The learning gap: Why our schools are failing and what we can learn from Japanese and Chinese education. Simon \& Schuster.

Stigler, J. W. \& Hiebert, J. (1997). Understanding and Improving Mathematics Instruction: An Overview of the TIMSS Video Study. Phi Delta Kappan, 79(1), 14-21.

Stigler, J. W. \& Hiebert, J. (1999). The teaching gap: Best ideas from the world's teachers for improving education in the classroom. The Free Press.

Stigler, J. W., Fernandez, C. \& Yoshida, M. (1996). Cultures of mathematics instruction in Japanese and American elementary classrooms. In T. P. Rohlen, \& G. LeTendre (Eds.), Teaching and learning in Japan (pp. 213-247). Cambridge University Press.

Stigler, J. W., Lee, S-Y. \& Stevenson, H. W. (1987). Mathematics Classrooms in Japan, Taiwan, and the United States. Child Development, 58(5), 1272-1285. https://doi. org/10.2307/1130620

Takahashi, A. \& McDougal, T. (2016). Collaborative Lesson Research: Maximizing the Impact of Lesson Study. ZDM, 48(4), 513-526. https:// doi.org/10.1007/s11858-015$\underline{0752-x}$

Takemura, S. \& Shimizu, K. (1993). Goals and strategies for science teaching as perceived by elementary school teachers in Japan and the United States. Peabody Journal of Education, 68(4), 23-33. https://doi.org/10.1080/01619569309538739

Yoshida, M. (1999a). Lesson study: A case study of a Japanese approach to improving instruction through school-based teacher development (doctoral dissertation). Chicago, IL: The University of Chicago.

Yoshida, M. (1999b). Lesson Study [jugyokenkyu] in elementary school mathematics in Japan: A case study. Paper presented at the AERA Annual Meeting, Montreal, Canada. 